\title{
Transformasi Sosial dalam Nilai-Nilai Pendidikan Islam di Kabupaten Sidenreng Rappang
}

\section{Elihami}

Email: elihamid@ymail.com

\section{STKIP Muhammadiyah Enrekang, Enrekang, Indonesia}

\section{Firawati, S.Pd.I.}

Guru TK PGRI Standar Corawali Kabupaten Sidenreng Rappang

\begin{tabular}{ll}
\hline Keyword & Abstrak \\
\hline Transformasi, & Penelitian ini bertujuan untuk menganalisis perubahan sosial dalam nilai-nilai \\
Perubahan & pendidikan Islam. Jenis penelitian ini adalah deskriptif yang bersifat kausalitas. \\
Sosial, Nilai- & Populasi penelitian ini adalah masyarakat kabupaten Sidenreng Rappang. Hasil \\
nilai dan & penelitian menunjukkan bahwa: Nilai atau sistem nilai yang dianut seseorang \\
pendidikan & atau suatu masyarakat mempunyai beberapa karakteristik. Pertama, nilai \\
Islam & merupakan hasil dari suatu proses intraksi manusia daslam kehidupannya. Dalam \\
& proses tersebut banyak faktor yang mempengaruhinya, baik faktor internal \\
& maupun eksternal. Kedua, nilai selalu berkaitan dengan kepentingan yang \\
bersangkutan. Dengan demikian, nilai merupakan respon yang dibuat seseorang \\
atau suatu masyarakat dengan bertitik tolak dari kepentingan masing-masing. \\
Ketiga, nilai yang diyakini tersebut tidak selalu berada dalam tataran yang sama. \\
Nilai memiliki hirarki. Ada nilai yang tertanam dalam pada pribadi seseorang, tapi \\
ada pula yang tidak begitu dalam diyakininya. Karakteristik nilai yang ketiga ini \\
ditentukan oleh karakteristik nilai yang pertama dan kedua. Keempat, nilai-nilai \\
yang ada dalam sisten nilai tidak selamanya sejalan. Dalam situasi tertentu \\
seseorang atau suatu masyarakat berhadapan dengan nilai yang bertolak \\
belakang yang sama-sama dianutnya. Dalam posisi demikian, nilai mana yang \\
dipilih itu ditentukan oleh karakteristik nilai pertama, kedua dan ketiga yang \\
dimilki oleh subyek pengambil keputusan tersebut.
\end{tabular}

\section{A. PENDAHULUAN}

Dalam al-Qur`an juga menunjukkan kepada manusia jalan terbaik guna merealisasikan dirinya, dalam mengembangkan dirinya dan mengantarkannya pada jenjang-jenjang kesempurnaan insani sehingga dengan demikian bisa merealisasikan kebahagiaan bagi dirinya baik di dunia maupun di akhirat.

Selain itu, al-Qur`an juga sangat mendorong manusia untuk belajar dan menuntut ilmu. Bukti terkuat mengenai hal ini ialah ayat al-Qur'an yang pertama kali diturunkan memberi dorongan kepada manusia untuk membaca dan belajar. Ayat ini juga menekannkan bahwa perantaraan Qalamlah, Allah swt. mengajarkan manusia membaca dan mengajarinya apa-apa yang belum diketahuinya.

Bahkan Islam lebih jauh menjelaskan, bahwa al-Qur`an adalah kalam Allah yang berisi segala hal mengenai petunjuk yang membawa hidup manusia bahagia baik di dunia maupun di akhirat. Karena kandungan yang ada di dalamnya meliputi segala sesuatu yang berhubungan dengan kehidupan manusia.

\#\# HowToCite\#\#

Elihami, Firawati Firawati. (2017).Transformasi Sosial dalam Nilai-Nilai Pendidikan Islam di Kabupaten Sidenreng Rappang. Edumaspul - Jurnal Pendidikan, 1(2), 51-60 
Salah satu aspek dari kekomprehensipan alQur`an adalah konsep al-Qur'an tentang pendidikan, atau aspek edukatif dalam alQur`an. Sebagaimana fakta menyatakan bahwa nama-nama yang telah dikenal yang diberikan pada pesan wahyu, lebih dari sembilan puluh nama kitab dan al-Qur`an. Misalnya ada dua nama yang populer yang berkaitan dengan masalah pendidikan dan pengajaran, yaitu alKitab dan al-Qur'an itu sendiri. Secara literal linguistik, al-Kitab berasal dari kata kataba yang berarti menulis dalam arti seluas-luasnya, yaitu mencatat, merekam, mendokumentasikan, mendeskripsikan, menguraikan, dan sebagainya. Sementara al- Qur`an berasal dari kata Qara 'ah yang berarti membaca dalam arti mengobservasi, mengklasifikasi, membandingkan, mengukur, menganalisis, menyimpulkan dan sebagainya.

Berbagai pengertian yang dimungkinkan tercakup dari kedua kata tersebut terlihat dengan jelas berkaitan langsung dengan masalah pendidikan, karena dengan membaca dan menulis memungkinkan seseorang mendapatkan ilmu pengetahuan, pengalaman, dan sebagainya. Demikian pula menulis dan membaca merupakan alat dalam transfer of knowledge (pengalihan atau pemindahan pengetahuan) yang sangat efektif.

Selanjutnya, jika dilihat surah pertama yang terdapat dalam susunan al-Qur`an yaitu surah al-Fatihah, maka pada ayat tersebut Allah memperkenalkan diri-Nya sebagai Rabbil Alamin, yaitu pemelihara, pembina, penuntun, pembimbing, pengembang, terhadap sekalian alam (Jalaluddin, 12).

Kata $R a b b$ tersebut selanjutnya berhubungan dengan rumpun kata tarbiyah yang berarti pendidikan.

Dari analisis secara sederhana tersebut terlihat dengan jelas bahwa al-Qur’an sebagai sumber utama ajaran Islam sangat menaruh perhatian yang sangat besar terhadap masalah pendidikan. Bahkan Abdurrahman Shalih Abdullah mengatakan bahwa al-Qur'an adalah kitab pendidikan. Oleh karena itu seseorang tidak mungkin dapat berbicara tentang pendididkan Islam tanpa mengambil al-Qur`an sebagai satusatunya rujukan. Karena al-Qur’an merupakan sumber utama ajaran Islam, dan rujukan terhadap pendidikan Islam, maka prinsipprinsip al-Qur'an harus menjadi jiwa dan pembimbing pendidikan Islam.

Islam sebgai agama yang universal mengandung suatu misi utama untuk mewujudkan rahmatan lil alamin, dan untuk mewujudkan misi tersebut, pendidikan Islam berada pada barisan terdepan, karena pendidikanlah yang secara langsung berhadapan atau bersentuhan dengan umat manusia. Ketentuan ini dapat dilihat dari alasan mengapa ayat yang pertama kali diturunkan sebagaimana disinggung di atas berbicara tentang pendidikan.

Dari pemaparan di atas, telah disinggung bahwa Islam sejak awal diturunkannya telah memberikan perhatian yang begitu besar terhadap kemajuan hidup manusia dengan memperhatikan untuk belajar (membaca) yang merupakan bagian penting dalam proses pendidikan (al-Alaq : 1-5). Bahkan sejak kejadian manusia pertama-Nabi Adam as.proses pendidikan ini telah disyariatkan oleh Allah swt. kepada manusia -Nabi Adam as.agar belajar, berpikir dan memahami tentang lingkungan kehidupan manusia ( QS. AlBaqarah ayat 31).

Oleh karena itu, dalam sejarah perkembangan manusia atau masyarakat, pendidikan senantiasa menjadi perhatian utama dalam rangka mewujudkan kehidupan dari generasi ke generasi, sajalan dengan tuntutan masyarakat dan keinginan manusia untuk selalu berkembang yang pada akhirnya akan senantiasa bermuara pada pola awal bahwa manusia adalah makhluk yang sangat memerlukan pendidikan.

Dari asumsi tersebut, mengindikasikan bahwa pendidikan merupakan ciri khas dalam kehidupan manusia sekaligus merupakan sarana yang sangat penting dalam membawa individu menjadi suatu pribadi yang mampu berdidri sendiri, dan berinteraksi dalam kehidupan sosial masyarakat secara konstruktif. Hal tersebut sesuai dengan ungkapan Hasan Langgulung yang mengatakan bahwa pendidikan dalam arti luas bermakna merubah dan memindahkan nilai kebudayaan kepada setiap individu dalam suatu komunitas masyarakat (Hasan Langgulung, 1985: 3).

Demikian pula pandangan klasik tentang pendidikan pada umumnya dikatakan sebagai pranata yang dapat menjalankan tiga fungsi sekaligus; Pertama, menyiapkan generasi muda untuk memegang peranan tertentu dalam masyarakat masa depan. Kedua, mentransfer pengetahuan (Transfer of Knowledge) sesuai peranan yang diharapkan. Ketiga, mentransfer nilai-nilai (transfer of value) dalam rangka memelihara keutuhan dan kesatuan masyarakat 
sebagai prasyarat bagi kelangsungan hidup (survive) masyarakat dan peradaban (Hasan Langgulung, 1980: 92).

Bukti kedua dan ketiga tersebut di atas memberikan sesuatu gambaran bahwa pendidikan bukan hanya berfungsi sebagai transfer of knowledge, tetapi sekaligus berfungsi sebagai transfer of value. Dalam perkembangan selanjutnya, ektensifikasi pendidikan tersebut sejalan dengan perkembangan tuntutan masyarakat. Dari hal tersebut melahirkan dua fungsi suplementer yaitu melahirkan tata sosial dan tata nilai yang ada dalam mayarakat dan sekaligus sebagai ajang pembaharu. Di sini terlihat adanya dimensi dinamis pendidikan.

Dari uraian di atas menegaskan bahwa Islam sebagai agama ynag berlandaskan pada al-Qur'an dan al-Sunnah merupakan pedoman hidup yang universal, eternal dan kosmopolitan. Universal artinya ajaran Islam berlaku dan merahmati seluruh alam dan segala isinya. Eternal artinya, berlaku sepanjang masa selama kehidupan dunia masih berlangsung, selalu kontekstual, dan up to date dengan segala persoalan hidup dan kemanusiaan. Dan Kosmopolitan artinya, secara garis besar dan dalam beberapa persoalan, secara rinci ajarannya mencakup semua aspek kehidupan manusia, atau paling tidak memberi arah dan nilai agar manusia tidak lepas kendali dan tetap mempunyai keterikatan primordial dengan nilai-nilai ketuhanan yang merupakan idealitas fitrahnya.

Dengan demikian, antara pendidikan dan masyarakat terjadi perpacuan (kompetisi) untuk maju. Dalam Islam sesuai risalah sucinya yakni meyebarkan agama, maka pendididkan merupakan kunci kemajuan yang mendorong pemeluknya dengan kesejahteraan yang berhasil diciptakannya, manusia secara individual dan sosial mampu meningkatkan derajat dan martabatnya, baik di dunia maupun di akhirat. Untuk itulah, maka manusia sangat butuh pada pendidikan dalam rangka mencapai kemajuan.

Namun proses transformasi global yang digerakkan oleh kekuatan sains, teknologi informatika dan transportasi sebagai akibat dari revolusi industri bangkit membentuk sebuah masyarakat baru yang berbeda dengan masamasa sebelumnya, yaitu masyarakat industri. Industrialisasi yang berpangkal pada mesinmesin industri, memberi pengaruh yang amat dalam terhadap pola kehidupan masyarakat.
Dalam konteks tersebut, yang menjadi persoalan adalah bahwa perubahan yang berlangsung tidak sepenuhnya membawa dampak positif. Akan tetapi di dalamnya juga terkandung dampak negatif bagi lingkungan, baik sosial maupun alam. Lebih dari itu, bahkan merubah pranata sosial yang telah mapan sekalipun. Aspek negatif yang demikian, tidak bisa dihindari secara sempurna oleh bangsa manapun juga, apalagi bagi bangsa-bangsa yang sedang dalam transisi seperti yang sedang dialami oleh bangsa Indonesia dari masyarakat agraris ke industrialisasi di tengah perkembangan dunia yang kian pesat. Dalam masyarakat yang demikian, pasti akan terjadi perubahan struktural dan kultural serta keterkejutan budaya yang tidak sejalan, atau bahkan saling berbenturan, sehingga terjadi anomie terhadap perangkat nilai yang berlaku.

Demikian pula, masuknya nilai-nilai dan paradigma barat ke dalam kawasan negaranegara berkembang, yang umumnya merupakan masyarakat yang taat terhadap agamanya, pada gilirannya menimbulkan permasalahan serius, sebab perkembangan tersebut selain berdampak pada tataran konstalasi teologis masyarakat, juga memaksakan nilai-nilai baru terhadap kehidupan masyarakat yang telah menyatu prilakunya dengan nila-nilai agamanya.

Bersamaan dengan itu, makin kuatnya mekanisme kehidupan sebagai bagian yang integral dari industrialisasi menciptakan tata hubungan kehidupan yang semakin jauh dari nilai-nilai mental-spiritual dan nila-nilai etika religius serta nilai-nilai sosio-kultural yang bersifat idealistis. Dalam kaitannya dengan proses komunikasi sosial, kepedulian moral dan sosial juga makin lemah intensitasnya, sehingga manusia sebagai makhluk sosial dan moral, mengalami kesenjangan sikap mental dan sosial antara kepentingan kesejahteraan hidup pribadi dengan kesejahteraan sosial. Akibatnya muncullah berbagai ragam gejala demoralisasi, dekadensi, egoisme dan individualisme serta apatisme dan sebagainya yang bersumber pada prustrasi yang semakin membengkak juga stres sosial (ketegangan batin masyarakat) yang sewaktu-waktu dapat meletup dan meledak ke permukaan kehidupan masyarakat.

Untuk menangkal kesemuanya ini, salah satu upaya yang dianggap ampuh adalah melalui jalur pendidikan, terutama pendidikan agama, khususnya pendidikan agama Islam. Karena ajaran dan aturan yang terdapat di dalamanya sudah baku dan mutlak karena ia 
adalah ketentuan dari Allah swt. Ia bukan buatan manusia (Al-Maidah (5): 48 atau QS. Al-Jatsyiah (45): 18). Oleh sebab itu, penanaman nilai-nilai luhur agama tersebut harus diupayakan menjadi milik masyarakat. Dalam hal ini, peranan pendidikan Islam memegang peranan utama dalam mengkomunikasikan dan mentransformasikan nilai-nilai agama tersebut.

Dalam kerangka pemikiran semacam ini, pendidikan Islam merupakan proses pemindahan nilai-nilai budaya yang bersumber dari al-Qur`an, al-Sunnah dan ijtihad. Nilainilai itulah yang diusahakan pendidikan Islam untuk dipindahkan dari satu generasi kepada generasi selanjutnya, sehingga terjadi kesinambungan nilai-nilai Islam ditengah masyarakat, (Zakiah Daradjad : 1996).

Dengan kesadaran semacam ini, diperlukan adanya usaha-usaha dan pikiran-pikiran yang segar dari generasi penerus intelektual muslim. Agar mereka dapat mewujudkan kreasi-kreasi baru dan menemukan identitas barunya untuk tidak sekedar melestarikan khazanah budaya umat terdahulu. Usaha tersebut dilakukan bermula dari penelaahan kembali terhadap ajaran Islam yang universal dan kosmopolitan untuk dirumuskan dan diaktualisasikan dalam konteks sistem pendidikan yang sedang berkembang.

Upaya semacam itu akan terwujud bila terdapat usaha-usaha reaktualisasi pendidikan Islam, yaitu suatu upaya mengangkat kembali pesan-pesan nilai-nilai Islam untuk dikembangkan dalam konteks perubahan sosialkultural dan sistem pendidikan yang ada. Agar nilai-nilai pendidikan Islam tetap eksis dan aktual dalam kehidupan transformasi sosial masyarakat. Disamping itu, perlu dilakukan Islamisasi pendidikan, yaitu mengangkat pesanpesan nilai-nilai Islam untuk mengarahkan perubahan sosio-kultural dan sistem pendidikan yang ada. Dengan kedua usaha inilah pendidikan Islam akan mampu memberikan konstribusi dan corak atau warna bagi sistem pendidikan yang ada dan sekaligus menunjukkan identitasnya yang tak pernah hilang.

\section{Hakekat Makna Nilai}

Pada hakekatnya pendidikan adalah suatu proses "memanusiakan manusia". Ini mengandung implikasi bahwa tanpa pendidikan maka manusia tidak akan menjadi manusia dalam arti yang sebenarnya, yaitu manusia yang utuh, dengan segala fungsinya, baik pisik maupun psikis. Ungkapan di atas juga mengandung makna bahwa pendidikan itupun telah berumur setua manusia, namun betapa sederhannya bentuk dan formatnya menurut ukuran kita sekarang. Ini terbukti dari kehadiran kita sekarang ini yang merupakan hasil dari rangkaian proses pendidikan yang telah berumur setua manusia itu. Karena manusia dan lingkungan selalu berkembang selama manusia itu ada maka, pendidikan pun berlangsung selama manusia itu hidup yang kini menjadi mode pendidikan diberbagai negara sebagai "pendidikan seumur hidup" (long life education).( Ahmad Ludjito: 1996)

Telah banyak definisi tentang pendidikan, dan sebanyak itu pula rumusan tentang tujuan pendidikan yang ditentukan atas dasar ideologi dan kepentingan suatu bangsa. Namun dari berbagai tujuan tersebut, dapat dirumuskan bahwa tujuan pendidikan adalah 'tercapainya kedewasaan' yaitu tercapainya titik optimal dari perkembangan semua potensi manusia, baik pisikal maupun spritual. Kedewasaan itu mencakup fungsi-fungsi individualitas, sosialita dan moralitasnya, sehingga tercapai kebulatan pribadi manusia sebagai pribadi dan anggota masyarakat yang untuk itu diperlukan moralitas. (Ahmad : 1996)

Untuk dapat menjabarkan potensi moralitas dalam kehidupan sehari-hari, diperlukan tentang berbagai nilai yang merupakan acuan dan tolak ukur dari sikap seseorang. Karena sikap dan nilai mempunyai peran yang penting dalam perkembangan moral individu. Sedangkan menurut Anker Nilsen sistem nilai (value syistem) merupakan unsur dinamis dari proses terjadinya integritas pribadi.

Nilai merupakan terminologi yang sering muncul tatkala kita membicarakan tentang filsafat, khususnya filsafat nilai atau axiologi. Walaupun sering dikemukakan, ternyata pengertian yang diberikan masih mengandung diskusi panjang lebar atau perbedaan pendapat dari kalangan para pakar tentang nilai atau axiologi tersebut.

Hal seperti ini tentu sangat menguntungkan karena di satu sisi, hal yang demikian menunjukkan perhatian yang semakin besar terhadap persoalan yang amat mendasar tersebut. Di sisi lain, dengan diskusi tersebut berarti diperoleh pemahaman yang lebih mendalan karena tentu terdapat masukanmasukan baru dan aktual yang berarti 
pengertian yang diberikan akan lebih relevan dengan kondisi yang ada.

Seperti disinggung di atas bahwa, nilai (value) merupakan masalah penting yang dibahas oleh filasafat tepatnya oleh cabang filsafat nilai atau axiologi. Tidak mengherankan apabila aksiologi disebut sebagai problems of human values. Aksiologi sebagai ilmu yang menyelidiki hakekat nilai yang pada umumnya ditinjau dari sudut pandang kefilasafatan (Lois O. Katt Shoff: 19987). Cabang filsafat ini merupakan salah satu dari tiga cabang pokok filasafat. Dua lainnya yaitu ontologi dan epistimologi.

Nilai biasanya dipahami dalam dua arti; Pertama, arti ekonomis yaitu yang berhubungan dengan kualitas atau harga sesuatu atau barang berwujud uang, termasuk nilai yang berwujud angka atau huruf. Kedua, nilai yang menunjuk pada suatu kriteria atau standar untuk menilai atau mengevaluasi sesuatu, seperti industrialisasi baik karena merupakan sarana bagi kemakmuran. Dalam pengertian ini terdapat berbagai jenis nilai; nilai individu, nilai sosial, nilai budaya dan nilai agama (Abd. AlHaq Anshari: 1988).

Nilai (value) dalam pandangan Brubacher tak terbatas ruang lingkupnya. Nilai tersebut sangat erat dengan pengertian-pengertian dan kativitas manusia yang kompleks, sehingga sulit ditentukan batasannya. Dalam Encyclopedy Brittannica dikatakan bahwa value is indetermination or quality of an object which involves any sorf or appriciation on interest bahwa nilai adalah suatu penetapan atau suatu kualitas objek yang menyangkut suatu jenis apresiasi ( Muh. Noer Syam: 1986).

Nilai itu praktis dan efektif dalam jiwa dan tindakan manusia dan melembaga secara obyektif di dalam masyarakat. Nilai itu merupakan suatu realita yang sah sebagai suatu cita-cita yang benar dan berlawanan dengan cita-cita palsu atau bersifat khayali. lain halnya dengan Risieri Frondizi dalam memahami masalah nilai, terlebih dahulu dia mereduksi nilai dengan menunjukkan tiga sektor besar realitas; benda, esensi, dan keadaan psikologis. Mula-mula usaha yang dilakukan untuk mereduksi nilai dengan kondisi psikologis. Kata sementara orang, nilai sama dengan sesuatu yang menyenangkan, kelompok yang lain menambahkan nilai identik dengan apa yang diinginkan kelompok ketiga berpendapat bahwa nilai merupakan sasaran perhatian kita, kenikmatan, keinginan. Perhatian merupakan susunan kejiwaan yang direduksi menjadi pengalaman pribadi semata.

Berlawanan dengan penafsiran yang bersifat psikologis terhadap nilai, muncul sebuah teori yang dengan cepat mendapat dukungan dan penghormatan yang besar yang mengatakan bahwa niali adalah esensi (ide platonik). Kesalahan yang dibuat dengan penggabungan nilai dengan esensi, sebagian disebabkan oleh pengacauan antara yang bukan realitas (tanda yang khas bagi nilai) dan identitas yang menandai esensi. Keabadian niali yang diasumsikan memberi dukungan besar pada ajaran yang berusaha memasukkan nilai ke dalam kategori yang sama sebagai objek ideal.

Selanjutnya, jika seorang berusaha meruduksi nilai dengan status benda tidaklah ada keraguan bahwa nilai tidak dikacaukan dengan objek material yang menutupinya, yaitu dengan tempat penyimpan atau pengembangnya. Kekacauan bermula dalam kenhyataan yang sangat riil bahwa nilai tidak ada dalam dirinya sendiri, namun tergantung pada pengembang atau penopangnya, yang pada umumnya adalah subtansi yang berbadan. Jadi keindahan misalnya tidak ada pada dirinya sendiri, seolah-olah mengawan di udara, namun yang mewujud di dalam objek pisik, kebutuhan akan pengembang untuk tinggal memberi sifat khusus pada nilai membuatnya menjadi eksistensi yang bersifat 'parasitis', namun kekhususan tersebut toidak dapat membenarkan pengacauan antara pendukung dengan yang didukung.

Dalam rangka menghindari pengacauan, maka ada baiknya dibedakan antara nilai dan benda. Benda adalah sama dengan sesuatu yang bernilai, yaitu suatu yang ditambah dengan nilai di dalamnya. Jadi sepotong pualam merupakan benda semata-mata; tangan pemahatlah yang menambahkan keindahan kepadanya yang sesuai dengan saran ironik dengan seorang pemahat. Dan benda yang berwujud pualam diubah bentuknya menjadi sebuah patung maka jadilah sesuatu yang baik (bernilai). Patung tersebut terus menerus menyimpan semua ciri khas pualam pada umumnya, dengan demikian, sesuatu yang ditambahkannya yang mengubahnya menjadi sebuah patung. Oleh karena itu, nilai buka merupakan benda atau pengalaman, juga buka merupakan esensi, tapi 'nilai' adalah nilai atau dengan ungkapan lain bahwa nilai itu bukan merupakan benda atau unsur dari benda melainkan sifat, kualitas, sui 
generis yang dimilki obyek tertentu yang dikatakan 'baik',(Risieri Frondizi: 2001).

Dalam pandangan Young, nilai diartikan sebagai asumsi-asumsi yang abstrak dan sering tidak disadari tentang hal-hal yang penting, sedangkan Green memandang nilai sebagai kesadaran yang relatif berlangsung dengan disertai emosi terhadap objek, ide, dan perseorangan. Lain halnya dengan Woods, ia menyatakan bahwa nilai merupakan petunjukpetunjuk umum yang telah berlangsung lama, yang mengarahkan tingkah laku dan kepuasaan dalam kehidupan sehari-hari (Wila Huky: 1982).

Dalam pengertian lain, nilai adalah konsepsi-konsepsi abstrak di dalam diri manusia atau masyarakat mengenai hal-hal yang dianggap baik, benar dan hal-hal yang dianggap buruk dan salah (HMI Cab. Bogor: 1989). Misalnya, nilai budaya, maksud konsepsi abstrak mengenai masalah dasar yang sangat penting dan bernilai dalam kehidupan manusia atau nilai keagamaan. Maksudnya adalah konsep mengenai penghargaan yang diberikan oleh warga masyarakat kepada beberapa masalah pokok dalam kehidupan beragama yang bersifat suci sehingga menjadi pedoman bagi tingkah laku keagamaan warga masyarakat yang bersangkutan (Tim Penyusun Kamus Besar Bahasa Indonesia).

Nilai bersifat ideal, abstrak, dan tidak dapat disentuh oleh panca indra. Sedangkan yang dapat ditangkap hanya barang atau tingkah laku yang mengandung nilai tersebut. Nilai juga bukan fakta yang berbentuk kenyataan dan konkrit. Oleh karena itu, masalah nilai bukan masalah benar dan salah, tetapi soal dikehendaki atau tidak, disenangi atau tidak, sehingga bersifat subyektif. Nilai tidak mungkin diuji dan ukurannya terletak pada diri yang menilai. Konfigurasi nilai dapat berwujud kebenaran yakni nilai logika yang memberi kepuasan rasa intelek, atau berwujud kegunaan diperoleh dari suatu barang. Hal ini karena barang tidak memilki kegunaan, sehingga tidak bernilai yakni nilai pragmatis (guna). Menurut Dick Hartoko bahwa nilai adalah hakekat suatu hal yang menyebabkan hal itu pantas dikerjakan oleh manusia; nilai berkaityan erat dengan kebaikan yang ada dalam inti suatu hal.

Jadi sesuatu dikatakan mempunyai nilai apabila ia mempunyai manfaat dalam kecamata manusia yang memberikan penilaiannya. Jadi nilai tidak lain sebenarnya adalah kualitas dari sesuatu. Ukuran dari kualitas itu adalah bermanfaat atau tidak bagi kepentingan manusia, baik kepentingan itu bersifat lahiriah atau batiniah. Karena berkaitan dengan kepentingan manusia, maka nilai merupakan kualitas yang selalu ingin diwujudkan. Niali tidak untuk disimpan sebagai kekayaan batiniah semata.

Dalam memberikan penilaian, subyek berhadapan dengan obyek. Karena pada hakekatnya subyeklah uyang akhirnya menentukan keputusannya tentang sesuatu nilai. Dalam memberikan penilaian itu, subyek dapat menggunakan segala kelengkapan analisis yang ada padanya, antara lain (1) indera yang dimilikinya yang dapat menghsilkan nilai nikmat dan sebaliknya nilai kesengsaraan. (2) Rasio yang dapat menghasilkan nilai benar atau salah. (3) Rasa etis yang dapat menghasilkan nilai baik dan buruk atau adil dan tidak adil. (4) Rasa estetis yang dapat menghasilkan nilai indah atau tidak indah. (5) Iman yang dapat menghasilkan nilai suci dan tidak suci, haram dan halal, (Darji Darmodiharjo: 1996).

\section{Sumber Nilai dalam Kehidupan Manusia}

Di atas telah diuraikan tentang hakekat makna nilai, kemudian dalam pembahasan ini akan diuraikan tentang sumber-sumber nilai dalam kehidupan manusia. khusus mengenai hal ini, ada banyak teori yang berusaha menjawab pertanyaan tentang dari mana nilai itu sesungguhnya berasal. Teori paling awal menyatakan bahwa semua nilai yang ada bersumber dari satu nilai lain yang lebih tinggi derajatnya. Nilai yang lebih tinggi ini dijelaskan dengan banyak sebutan yang berbau transendental, misalnya kehendak para dewa (The Will of God), jiwa alam (the world soul), hasrat jiwa (yearnings of the soul), kausa prima (the final cause), bidang ide-ide (the realm of ideas).

Para tokoh idealis modern cenderung menekankan pada sisi obyektif dari nilai mereka lebih mengidentifikasikan nilai dengan sesuatu yang lebih dekat denga kita tanpa menghilangkan konsepsi nilai seperti yang telah disebutkan di atas. Nilai diidentifikasikan antara lain sebagai aturan alam (the order of universe), rasionalitas kosmos (Cosmic rasionality) atau bahkan sifat ketuhanan dalam diri manusia (the devine within use). Menurut penafsiran mereka, sumber utama nilai terletak pada sesuatu di luar diri manusia. kita dapat menciptakannya tapi hanya menemukannya. Ada beberapa tokoh idealis yang memberikan kesimpulan umum 
tentang itu, misalnya WM. Urban mengatakan bahwa nilai dan realitas tidak terpisahkan satu dengan yang lainnya. Juga AN. White Heart dalam bukunya relegion in the Making menyebutkan nilai sebagai sesuatu yang inheren di dalam aktualityas itu sendiri. Tokoh idealis yang lain seperti pemikir Inggris Bernald Bosanchust berpendapat bahwa nilai adalah kualitas tertentu dari objek, dalam mana dimanifestasikan dalam sikap batin manusian.

Pandangan kaum idealis ini telah menyumbangkan pemikiran tentang sumber nilai dari sudut yang lebih obyektif, namun tidak dapat disimpulkan sebagai pandangan yang selamanya tepat, seperti telah disinggung di atas dalam banyak hal nilai lebih bersifat subjektif daripada obyektif.

Terlepas dari pendapat tersebut, teori tentang sumber nilai dapat disebutkan ada tiga sumber.1 Pertama, teori yang mengatakan bahwa sesuatu itu bernilai atau tidak ditentukan oleh kehendak Tuhan. Tuhanlah yang menetapkan kualitas dari sesuatu itu. Teori tersebut dapat menjelaskan dengan baik tentang nilai dasar, tetapi menghadapi kesukaran dalam menjelaskan tentang nilai instrumental dan praktis. Di samping itu, banyak sekali masalahmasalah nilai yang muncul kemudian, yang sulit dicari rujukannya dalam kitab-kitab suci yang tentu saja menimbulkan kontropersi tentang baik buruk alternatif penyelesainnya. Kontropersi ini tidak saja terjasi dalam dialog antara agama, namun kerap terjadi dalam kalangan intern agama yang sama.

Kedua, ada yang mengatakan bahwa nilai berasal dari hati nurani manusia. apa yang baik dan tidak baik, indah dan tidak indah berpulang kepada hati nurani manusia masing-masing. Suara hati tidak sama dengan perasaan karena perasaan itu identik dengan subyektifitas. Seperti yang dikatakan oleh Frans Magnis Suseno, suatu hati adalah kesadaran akan kewajiban dalam situasi konkrit. Jadi suara hati pun dapat saja obyektif yang pentingf harus didukung oleh pertimbangan-pertimbangan yang rasional.

Pendapat bahwa suatu hati nurani dapat obyektif dibantah oleh sebagian filosof yang digolongkan sebagai penganut Emotivisme mereka mengatakan bahwa apapun yang dipakai suara hati tetap tidak terlepas dari perasaan. Penilaian benar atau salah, baik atau tidak baik tergantung pada ungkapan sikap orang terhadap suatu pristiwa.
Untuk mengatasi ketidakpuasan atas teori tentang suara hati ini dijawab dengan munculnya teori ketiga yang lebih belakangan dengan mengatakan bahwa sumber nilai adalah aturan alam atau rasionalitas kosmos.

Sumber lain mengatakan bahwa sumber nilai yang berlaku dalam pranata kehidupan manusia dapat digolongkan menjadi dua macam yaitu:

\section{Nilai Ilahiyah.}

Nilai Ilahiyah, yaitu niali yang difitrahkan Allah swt. melalui rasul-Nya yang berbentuk taqwa, iman, adil yang diabadikan dalam wahyu Ilahi.

Religi merupakan sumber pertama dan utama bagi para penganutnya. Dari religi itu disebarkan nilai-nilai untuk diaktualisasikan dalam kehidupan sehari-hari. Nilai ini bersifat statis dan kebenarannya bersifat mutlak.

Nilai-nilai selamanya tidak mengalami perubahan, nilai-nilai yang fundamental mengandung kemutlakan bagi kehidupan manusia selaku pribadi dan anggota masyarakat, serta tidak berkecenderungan untuk berubah mengikuti selera hawa nafsu manusia dan berubah-ubah sesuai dengan tuntutan perubahan sosial dan individual. Konfigurasi dari nilai-nilai Ilahi mungkin dapat mengalami perubahan, namun secara intrinsik tetap tidak berubah. Hal ini karena bila intrinsik nilai tersebut berubah maka kewahyuan (revilatif) dari sumber nilai yang berupa kitab suci akan mengalami kerusakan (H.M. Arifin: 1991).

Pada nilai-nilai ini, tugas manusia adalah menginterpretasikan nilai-nilai itu. Dengan penafsiran yang demikian manusia akan mampu dengan mudah menghadapi ajaran agama yang dianut, (Noeng Muhajir: 1987).

\section{Nilai Insaniyah}

Nilai insaniyah yaitu nilai yang tumbuh atas kesepakatan manusia yang hidup dan berkembang dari peradaban manusia. Nilai tersebut bersifat dinamis, sedangkan keberlakuan dan kebenarannya relatif atau nisbi yang dibatasi oleh ruang dan waktu.

Pada nilai insaniyah ini, fungsi tafsir lebih memperoleh konsep nilai itu atau lebih memperkaya isi konsep atau untuk memodifikasi bahkan mengganti dengan konsep-konsep baru. Nilai-nilai insani yang kemudian melembaga menjadi tradisi-tradisi yang diwariskan turun temurun dan mengikat 
anggota masyarakat yang mendukungnya karena kecenderungan tradisi tetap mempertahankan diri terhadap kemungkinan perubahan tata nilai. Kenyataan ikatan tradisional sering menjadi penghambat perkembangan peradaban dan kemajuan manusia. di sini terjadi kontradiksi antara kepercayaan yang diperlukan sebagai sumber tata nilai guna menopang peradaban manusia. akan tetapi nilai-nilai itu melembaga dalam tradisi yang membeku dan mengikat yang justru dapat merugikan peradaban. Dari itulah perkembangan peradaban menginginkan adanya sikap meninggalkan bentuk kepercayaan dan tata nilai tradisional dan menganut kepercayaan dan nilai-nilai yang sungguh-sungguh merupakan suatu kebenaran.

Dalam perspektif Islam khususnya dalam konteks Al-Islam dan Kemuhammadiyahan tidak semua nilai yang telah melembaga dalam suatu tatanan kehidupan masyarakat Muhammadiyah diterima atau ditolak (Elihami, 2016). Hal ini karena Islam mengandung nilai universalitas yang cukup memberi peluang setiap pemeluknya untuk berbeda 'a change Islamic education usually extrims and fundamentalism'. (elihami, 2016). Sikap Islam dalam menghadapi tata nilai masyarakat ini adalah menggunakan lima macam klasifikasi yaitu :

1. Memelihara unsur-unsur nilai dan normanorma yang sudah mapan dan positif.

2. Menghilangkan unsur-unsur dan norma yang sudah mapan tetapi negatif.

3. Menumbuhkan unsur-unsur nilai dan norma baru yang belum ada dan dianggap positif.

4. Bersikap menerima (reseptif), memilih, mencerna, menggabung-gabungkan dalam suatu sistem (asimilatif), dan menyampaikan pada orang lain (transmisif) terhadap nilai pada umumnya.

5. Menyelenggarakan pengkudusan atau penyucian nilai atau norma agar sesuai dan sejalan dengan nilai dan norma-norma Islam itu sendiri. Tegasnya adalah menyelenggarakan islamisasi nilai dan norma,( Endang Saefuddin:1982).

Dengan demikian akan terwujud hubungan yang ideal antara nilai agama Islam dan nilai yang berlaku dalam masyarakat yaitu terbinanya nilai masyarakat yang dijiwai dan ditopang oleh nilai-nilai abadi dan universal yang terdapat pada wahyu Ilahi.
Walaupun Islam memilki nilai-nilai samawi yang bersifat absolut dan berlaku universal, namun Islam masih mengakui adanya nilai tradisi masyarakat. Hal tersebut karena tradisi merupakan warisan yang sangat berharga dari masa lampau yang harus dilestarikan sejauh mungkin tanpa menghambat tumbuhnya kreativitas individual. Di samping itu, tradisi merupakan persambungan yang tidak dapat begitu saja dihilangkan tanpa menimbulkan akibat-akibat besar bagi kehidupan individu dan masyarakat, terutama bagi tujuan penciptaan pola kehidupan yang melestarikan sumbersumber, bahan, daya dan tenaga (al-'Adah alMuhakkamah) adat kebiasaan dapat dijadikan hukum. Akan tetapi, tradisi itu harus didinamisasikan guna menghindari kebekuan dan kelambanan yang dapat menghambat kreatifitas individu. Penekanannya harus dilakukan pada kemampuan tradisi dan penyesuaiannya pada tuntutan perubaha, sehingga esensi dari tradisi dapat dikembangkan dalam situasi yang senantiasa berubah-ubah,(Abd. Rahman Wahid: 1981).

Sebagaimana suatu postulat yang sudah populer yang mengatakan bahwa : $\mathrm{Al}$ Muhafadzah 'ala al-Qadim al-Shalih wa alAkhzu bi al-Jadid al-Ashlah ( melestarikan nilai-nilai lama yang positif dan mengambil nilai-nilai baru yang lebih positif), (Muhammad Tholchah Hasan:1982).

Selanjutnya, antara nilai Ilahi dan nilai insani mempunyai relasi. Nilai Ilahi memilki kedudukan vertikal lebih tinggi daripada nilai hidup lainnya. Di samping hirarkinya lebih tinggi, nilai keagamaan mempunyai konsekuensi pada nilai lainnya dan sebaliknya nilai lainnya itu memerlukan konfirmasi pada nilai pada nilai etis-religius.

Relasi atau hubungan antara nilai insani dengan Ilahi dapat dipadukan dan diringkaskan menjadi empat macam, yaitu:

\section{Literal-horisontal}

Nilai-nilai insani mempunyai hubungan sederajat yang indefendent dalam arti dapat saling berkonsultasi atau tidak terpisah antara nilai yang satu dengan yang lainnya.misalnya nilai sosial, ekonomi, politik dan lain sebagainya.

\section{2. literal-sekuensial.}

Nilai-nilai insani mempunyai hubungan sederajat yang saling berkonsultasi, misalnya terapan, nilai rasional, juga harus diimbangiu 
dengan konsekuensi bio-fisiknya seperti menjaga kesehatan, makan dan istirahat, sehingga hubungan antara nilai rasional dan bio-fisik sederajat dan saling bergantung. Demikian pula antara individu dan sosial yakni terapan nilai individual harus mempertimbangkan konsekunsi sosialnya, demikian pula sebaliknya.

\section{Linear-Sinkron}

Hubungan hirarki yang etis Insani lebih tinggi dari yang manusiawi lainnya, dan berfungsi menyatukan.

\section{Linear-koheren.}

Ada hubungan hirarki, yang etis Ilahi menjadi tempat konsultasi dan menjadi pemandu semua nilai. Dengan demikian, apapun pendapat tentang sumber nilai, yang jelas bahwa nilai itu mewngandung pengertian yang abstrak. Nilai memang merupakan suatu kualitas, tetapi sulit untuk menerangkan apa kualitas itu sebanarnya, karena demikian luas maknanya bigitupula sifatnya. Sesuatu dikatakan bernilai tergantung pada bagaimana proses kehidupan yang dijalani seorang manusia.

Nilai atau sistem nilai yang dianut seseorang atau suatu masyarakat mempunyai beberapa karakteristik. Pertama, nilai merupakan hasil dari suatu proses intraksi manusia daslam kehidupannya. Dalam proses tersebut banyak faktor yang mempengaruhinya, baik faktor internal maupun eksternal. Kedua, nilai selalu berkaitan dengan kepentingan yang bersangkutan. Dengan demikian,nilai merupakan respon yang dibuat seseorang atau suatu masyarakat dengan bertitik tolak dari kepentingan masing-masing. Ketiga, nilai yang diyakini tersebut tidak selalu berada dalam tataran yang sama. Nilai memiliki hirarki. Ada nilai yang tertanam dalam pada pribadi seseorang, tapi ada pula yang tidak begitu dalam diyakininya. Karakteristik nilai yang ketiga ini ditentukan oleh karakteristik nilai yang pertama dan kedua.Keempat, nilai-nilai yang ada dalam sisten nilai tidak selamanya sejalan. Dalam situasi tertentu seseorang atau suatu masyarakat berhadapan dengan nilai yang bertolak belakang yang sama-sama dianutnya. Dalam posisi demikian, nilai mana yang dipilih itu ditentukan oleh karakteristik nilai pertama, kedua dan ketiga yang dimilki oleh subyek pengambil keputusan tersebut.

\section{PENUTUP}

Dari pemaparan tersebut di atas, maka dapat dikesimpulan bahwa Pendidikan Islam merupakan rangkaian proses pembimbingan, pembelajaran atau pelatihan untuk mengarahkan potensi hidup manusia berupa kemampuan-kemampuan dasar, sehingga terjadi perubahan dalam kehidupan pribadinya sebagai makhluk individual, sosial, dan dalam hubungannya dengan alam lingkungan sekitarnya. Agar nantinya menjadi orang Islam yang berkehidupan serta mampu melaksanakan peranan dan tugasnya sebagai orang muslim.

Pendidikan Islam diarahkan untuk mencapai pertumbahan pribadi-pribadi manusia secara menyeluruh melalui latihan-latihan kejiwaan, akal pikiran, kecerdasan dan perasaan. Dengan kata lain, pendidikan Islam diarahkan untuk mengembangkan seluruh aspek kehidupan manusia (jasmani dan rohani), baik secara individual maupun kelompok, agar dapat mencapai kesejahteraan dan keselamatan hidup, baik di dunia maupun di akhirat.

Pendidikan Islam merupakan suatu proses pemindahan atau pewarisan nilai-nilai, baik nilai-nilai ilahiyah yang berbentuk taqwa, iman, keadilan dan sebagainya, maupun niali-nilai insaniyah yang tumbuh dan berkembang dari peradaban manusia. Dan nilai-nilai itulah yang diusahakan untuk dipindahkan dan diwariskan dari satu generasi ke generasi selanjutnya, sehingga terjadi kesinambungan nilai-nilai ajaran Islam (nilai-nilai pendididkan Islam) di tengah kehidupan sosial- masyarakat.

\section{DAFTAR PUTAKA}

[1] Rasdiyanah. Strukturisasi Lembaga Pendidikan Islam Dalam Menghadapi Tantangan Masa Depan, dalam Jurnal Pendidikan Fakultas Tarbiyah IAIN Alauddin, Edisi perdana, 1999.

[2] A.S. Hornby, EV. Gatenby, H. Wake Field, The Advanced Learner's Dictionary of Current English, Oxford: Second Edition, 1962

[3] Abdullah , Amin. Agama dan Akal Pikiran, Cet. II; Jakarta: Rajawali Pers, 1989.

[4] Ahmad Tafsir, Ilmu Pendidikam Dalam Perspektif Islam, Cet. I ; Bandung : Remaja Rasda Karya, 1992. 
[5] Ahmad, Mudlor. Manusia dan Kebenaran; Masalah Pokok Filsafat Surabaya: Usaha Nasional, t. th.

[6] Ahmadi, Islam sebagai Paradigma Ilmu Pendidikan, Cet. I; Yokyakarta: Aditya Media, 1992.

[7] al-Ahwani, Ahmad Fuad. Al-Tarbiyah fi al-Islam, Mekah : Dar al-Ma'arif, 1975.

[8] al-Attas, Muhammad Naquid. Aims and objective of Islamic education

[9] al-Jalal, Abd al-Fattah. Min al-Ushul alTarbawiyah fi al-Islam (Kairo; alMarkas: al-Duali li al-Ta`lim, 1988

[10] Al-Khouly, Muhammad Ali. Qamus Tarbiyah, Inggris, Arab, Bairut, Libanon : Darul Ilmu Al-Maliyia t. th.

[11] Al-Nahlawi, Abdurrahman. Pendidikan Islam Dirumah, sekolah dan masyarakat, Cet. II ; Jakarta : Gema Insani Press, 1996.

[12] Anshary, Abd al-Haq . Islam and The Modern Age, A Quartly Juranal, vol. VIII; No.4, 1977.

[13] Ardhana, Wayan. (Pent.), Dasar-dasar Kependidikan (FIP -IKIP Malang, 1986.

[14] Asy-Syuyuti, Jalaluddin . Al-Itqan Ulum al-Qur'an Cet. III; Mesir:

[15] Azra, Azumardi. Pendidikan Islam, Tradisi dan Modernisasi menuju Milenium Baru Cet. I; jakarta : Logops, 1999

[16] Barnadib, Imam. Filsafat Pendidikan; Pengantar Mengenai Sistem dan Metode, Cet. I; Yokyakarta: Andi offset, 1988.

[17] Crow and Crow, Pengantar Ilmu Pendidikan, Edisi III; Yogyakarta : Rake Sarasin, 1990.

[18] D. Marimba, Ahmad. Pengantar Filsafat Pendidikan Islam, Cet. II ; Bandung : AlMu'arif, 1980.
[19] D. Mc Neil, John. Kurikulum; Sebuah Pengantar Konfrehensif, Cet. I; Jakarta : Wirasabi, 1988.

[20] Dahrendorf, Ralf. Konflik dan Konflik Kelas dalam Masyarakat Industri Cet. I; Jakarta: CV. Rajawali, 1986.

[21] Daradjad, Zakiah. Ilmu Pendidikan Islam Cet.III; Jakarta: Bumi Aksara, 1996.

[22] Darmodiharjo, Darji. Orientasi Singkat Pancasila, Jakarta: Gramedia Pustaka Utama.

[23] Departemen Agama RI., Al-Qur'an dan Terjemahnya, Semarang : Toha Putra, 1989.

[24] Djuwaeli, H. M. Irsyad . Pembaharuan Pendidikan Islam, Cet. I; Ciputat : Karsa Utama Mandiri, 1998.

[25] Durkheim, Emile. The Divition of Labour in Society Cet.I; New York: The free Press, 1964

[26] Elihami. (2016). Keislaman. Cet.1; Yogyakarta: Deepublish.

[27] Elihami. (2016). The Challenge of Religious Education in Indonesia Multiculturalism. Vol. 5, No. 4, pp.211221. American Research Institute for Policy Development.

[28] Elihami. (2016). Meningkatkan hasil belajar Al-Islam dan Kemuhammadiyahan melalui kuis pada mahasiswa PGSD kelas A di STKIP Muhammadiyah Enrekang. Volume 1, Nomor 1; Aceh: Jurnal Mudarrisuna. 